\title{
The Al-Ula GCC Summit: An End to Gulf Rivalry or Just Another Truce?
}

\author{
MARWAN KABALAN \\ Arab Center for Research and Policy Studies, Qatar \\ ORCID No: 0000-0001-9728-7375
}

AвSTRACT Three-and-a-half-years into the crisis that struck the heart of the Gulf Cooperation Council (GCC), the $41^{\text {st }}$ Gulf Summit, held on January 5, 2021, in the Saudi city of al-Ula, brought the blockade of Qatar to an end. The summits final communiqué stated that the GCC member states will "stand together as one to confront any threat to the security of the block" and prevent any "violation of sovereignty of any member state." According to the Saudi Foreign Minister, Faisal bin Farhan, "points of disagreement with Qatar have been solved." The Saudi minister declined to give more details on the compromises the two sides may have agreed on and the timeframe for their implementation. Lack of enthusiasm in the state-owned media on both sides of the fence suggests, however, that the agreement will merely return the relationship between the parties to the pre-June 5, 2017 position. So far, the two sides blame COVID-19 for 'social distancing.' Trade has not been fully resumed and cross-borders movement of goods and peoples remain low. It is assumed that cold peace is likely to prevail until the two sides re-establish mutual trust, which was badly damaged, especially at the level of the heads of states.

Keywords: Gulf Crisis, Al-Ula GCC Summit, President Trump, Riyadh Summit, Al Jazeera, AntiQatar Alliance

Insight Turkey 2021

Vol. 23 / No. 1 / pp. 51-59

Received Date: 01/02/2021 • Accepted Date: 21/02/2021 • DOI: 10.25253/99.2021231.5 


\section{Roots of the Gulf Crisis}

T he Gulf crisis began only two days after the May 21, 2017, Riyadh summit, the declared goal of which was to confront terrorism and contain Iran. Co-chaired by Saudi King, Salman Bin Abdulaziz, and former U.S. President, Donald Trump, the summit was attended by representatives from about 50 Arab and Islamic countries. On May 24, the Qatar News Agency (QNA) was hacked and fabricated statements attributed to the Emir of Qatar during a graduation ceremony for cadets at a military college were published. A media campaign against Qatar ensued, culminating in the June 5, 2017 announcement of Saudi Arabia, the United Arab Emirates (UAE), Bahrain, and Egypt of severing diplomatic ties with Doha. The measures also included closing land, sea, and air access from and to Qatar.

This was not the first crisis between Qatar and its Gulf neighbors, yet it was by far the worst. In February 2014, the three Gulf States withdrew their ambassadors from Doha. Disagreement over the 2011 Arab revolutions, and particularly the position on Egypt's 2013 military coup, which overthrew President Mohamed Morsi, was the main cause of the 2014 crisis. Good offices by the late Emir of Kuwait, Sabah al-Ahmad al-Sabah, succeeded in containing the situation. Negotiations pursued over an eight-month period led to the November 2014 Riyadh Agreement and ambassadors of Saudi Arabia, UAE, and Bahrain were returned to Qatar.
Reconciliation allowed the $35^{\text {th }}$ Gulf summit to convene in Doha in December 2014 with all member states attending. The 2014 Gulf crisis was contained without further punitive measures against Qatar because the three GCC nations were gripped by anxiety over the Obama Administration's policies in the region. Obama's conciliatory approach toward Iran and his obsession with reaching a nuclear agreement with Tehran created a sense of U.S. abandonment amongst the Arab Gulf states. Saudi Arabia and the UAE agreed, as a result, to end the crisis with Qatar. Indeed, the two Gulf nations were also in need of Qatar's media, financial and military support as the planning for their military intervention in Yemen was underway following the Houthi takeover of Sanaa in September 2014.

\section{The Trump Factor}

The ascendance of Donald Trump to power at the beginning of $2017 \mathrm{had}$ a huge impact on Arab politics. Saudi Arabia, the UAE, Bahrain, and Egypt saw the end of the Obama tenure as an opportunity to return to a full partnership with Washington D.C., following a period of tension resulting from the Arab spring revolutions and the U.S.-Iran rapprochement. President Trump's declared intention to end the Obama legacy, including the Iran nuclear deal, emboldened the four Arab nations in their endeavor to isolate and weaken Qatar. ${ }^{3}$ In fact, President Trump championed the demands of the anti-Qatar alliance. ${ }^{4} \mathrm{He}$ even appeared to take credit for the 
move to isolate Qatar, suggesting that it was inspired by his insistence on Gulf rulers during the Riyadh Summit that more is done to combat and restrict the financing of terrorism. 5 "So good to see Saudi Arabia visit with the King and 50 countries already paying off. They said they would take a hard line on funding ${ }^{6} . .$. extremism, and all reference was pointing to Qatar. Perhaps this will be the beginning of the end to the horror of terrorism!" President Trump tweeted. ${ }^{7}$

Having acknowledged the centrality of the U.S. position in the crisis, Qatar sought to sway President Trump and eventually change his stance. The last summit meeting that President Trump held with the Emir of Qatar in July 2019 showed the scope of change in Trump's position. The joint statement issued following the meeting at the White House emphasized the "strategic relationship between the two countries." Up until that point, Kuwait's mediation had not succeeded in bringing about any substantial change in the position of the four Arab countries vis-à-vis Qatar. With increasing U.S. support for Kuwait's mediation efforts, the crisis started to show signs of improvement. In the final weeks of the Trump presidency, mediation efforts culminated in reaching an agreement in which Jared Kushner, President Trump's son-inlaw and advisor, played a key role in mediating between Qatar and Saudi Arabia. The breakthrough in the crisis came during Kushner's regional tour in early December 2020, when Saudi Arabia and Qatar agreed on a joint declaration to end the dispute. Saudi

\section{The 2014 Gulf crisis was} contained without further punitive measures against Qatar because the three GCC nations were gripped by anxiety over the Obama Administration's policies in the region

Arabia was entrusted with the task of bringing the other three nations on board. Four weeks later, the $41^{\text {st }}$ Gulf Summit convened in the Saudi city of al-Ula, instead of Manama, with the Emir of Qatar heading his country's delegation to the summit.

\section{The Crisis of the GCC}

For over three years, Kuwait exerted tremendous efforts to end the crisis between Qatar and its neighbors and prevent the possible collapse of the GCC. In 2019, Kuwaiti mediation efforts came close to success on two separate occasions. The first was in May when Qatar's prime minister attended the GCC, Arab, and Islamic summits in Mecca, Saudi Arabia, to show solidarity with the kingdom following a number of attacks on oil tankers in the Arabian Gulf and the Gulf of Oman. The second occasion was when Bahrain, Saudi Arabia, and the UAE participated in the $24^{\text {th }}$ Arab Gulf Cup football tournament that took place in Doha in November 

Leaders from
the Gulf nations
pose for a photo
during the $41^{\text {st }}$
Summit of Gulf
Cooperation
Council, in al-Ula,
Saudi Arabia,
January 5, 2021.
Qatari Emirate
Council / AA

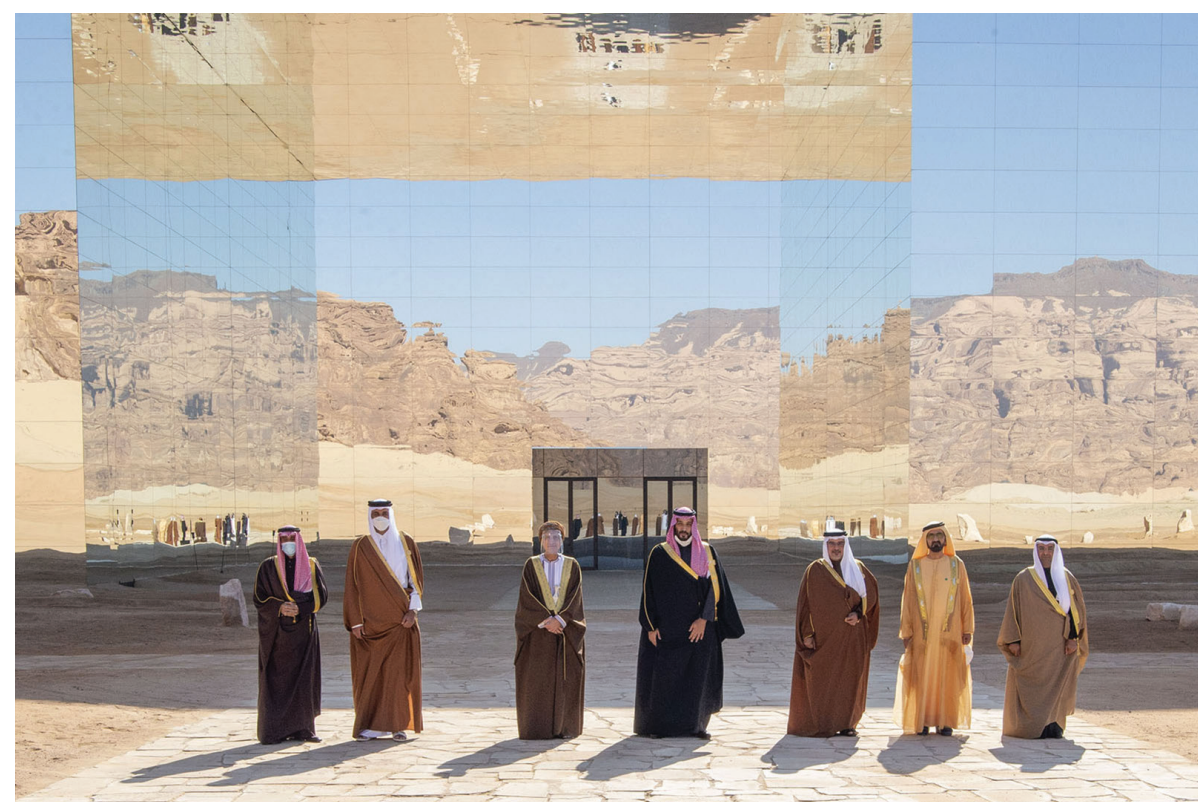

2019. The surprising decision of the three Gulf nations to take part in the tournament raised hopes of a possible end to the crisis. Qatar also dispatched its prime minister to the December 2019 GCC summit in Riyadh, hoping that it would help to end the dispute. Qatari Foreign Minister, Mohammed bin Abdul Rahman alThani, paid a secret visit to Riyadh in late 2019 to address the problem. ${ }^{9}$ No breakthrough was made, however.

The UAE was blamed for the lack of progress. Abu Dhabi was seen as holding the Saudis back from accepting a settlement to the crisis. Indeed, Abu Dhabi was particularly inflexible when it came to reconciliation with Qatar; yet by the time the crisis broke out in 2017, it was already clear that the GCC was no longer sharing the same values, threat perceptions, or foreign policy objectives.
In 1981, when Sheikh Jaber al-Ahmad al-Sabah, the former ruler of Kuwait, called for the establishment of an Arab Gulf collective security organization, there was an agreement among the six-member states that revolutionary Iran represented an existential threat for the proU.S. Gulf monarchies. That seems to have changed now. The revelation by the former Emir of Kuwait, Sabah al-Ahmad al-Sabah, that his good offices had prevented military action against Qatar in the summer of 2017 left no doubt about this. ${ }^{10}$ It was the first time that a full military invasion seemed to have been contemplated by members of the GCC against another member, and in coordination with a non-member state (Egypt).

The Gulf crisis has served to refute the existence of a collective security regime among the GCC countries. It 
showed that they share neither similar values nor common interests. Their conflict also concealed different worldviews and diverse leadership visions about the region and its future. Although it is not a democracy, Qatar challenges the status quo and supports the cause of democracy across the Arab world, mainly through the Al Jazeera news channel. This goes against the very logic of the GCC, a club of rich, conservative, and non-democratic countries that strive to maintain the status quo.

Qatar and Al Jazeera were blamed for the 2011 Arab revolutions that resulted in the fall of the Mubarak regime in Egypt. With Mubarak out of the picture, Qatar was perceived to have succeeded in challenging the status quo and in engineering a new Middle East power structure. Saudi Arabia and the UAE could not tolerate such a profound change in the regional environment. They supported and funded the July 2013 military coup in Egypt that deposed the democratically elected president, Mohamed Morsi, and reinstated the old regime, but without Hosni Mubarak. The coup exposed the deep rift between the GCC countries, leading to the 2014 crisis.

The 2017 crisis, with its unprecedented measures against Qatar, demonstrated that the GCC might have just lost the very foundations of its existence. With no shared values or common interests and without agreement on threat perceptions, there seems to be very little impetus left for the GCC to function as one

\section{By rethinking some of its} policies, primarily the dispute with Qatar, Saudi Arabia was trying to avoid pressure from the new U.S. administration

block. Reconciliation at the al-Ula summit may have ended the Qatar blockade but did not address the core differences that divide Qatar from its neighbors.

\section{Motives for Reconciliation}

As much as the ascendance of Donald Trump to power played a key role in igniting the 2017 Gulf crisis, his departure four years later was similarly vital in ending it. The victory of Joe Biden in the November 2020 U.S. presidential elections led to a major shift in Saudi calculations. Saudi Arabia, which enjoyed strong ties with the Trump Administration, became open to pressure from the Biden Administration. During his election campaign, Biden pledged to revise relations with Saudi Arabia and reconsider a number of policies towards Riyadh, including arms sales, human rights issues, and Washington D.C.'s support for the war in Yemen. ${ }^{11}$ Biden was under pressure from within his own Democratic Party, especially from the far left, to end U.S. support for Saudi Arabia and punish those responsible for the murder of Saudi journalist Jamal Khashoggi. Saudi Arabia was also disenchanted with 
The economic crisis resulting from the double shock of

the collapsing oil prices and

COVID-19 has also forced both

Saudi Arabia and the UAE to

take a less aggressive foreign

policy attitude, including

toward Qatar demic. The pandemic hit major sectors of the GCC economies, including tourism, construction, and trade. The pandemic caused a major decline in global oil consumption, reducing significantly the income of the Gulf countries, which rely heavily on oil revenue. The impact on tourism was similarly catastrophic. Saudi Arabia and the UAE in particular were badly hit by a very calm season. Dubai was forced to postpone Expo 2020 for a year. ${ }^{13}$ Saudi Arabia was also forced to cancel the $2020 \mathrm{Haj}$ season and has therefore lost around two percent of its annual income. ${ }^{14}$ According to the Institute of International Finance (IIF), Saudi Arabia's economy shrank by 4 percent in 2020 and its deficit reached 13 percent. ${ }^{15}$ The impact of the double shock of plunging oil prices and the coronavirus pandemic has led to scaling back the aggressive foreign policies of Saudi Arabia and the UAE, and the Qatar blockade was one of them.

By rethinking some of its policies, primarily the dispute with Qatar, Saudi Arabia was trying to avoid pressure from the new U.S. administration. The decision to end the crisis with Qatar, despite opposition from its allies, was also a deliberate move by the Saudis to show that they were the ones who call the shots in the GCC.

Worsening economic conditions have also played a key role in bringing to an end the worst intra-Gulf crisis. In 2020, the GCC countries faced their worst economic crisis ever amid the double shock of plunging oil prices and the COVID-19 pan-
The personal motivations of Saudi Arabia's crown prince, Mohammed bin Salman, may have also played a role in ending the crisis with Qatar. The catastrophic humanitarian crisis resulting from the war in Yemen, which was described by the UN as the world's worst humanitarian crisis; and the brutal murder of Saudi journalist Jamal Khashoggi at his country's consulate in İstanbul in October 2018 have tarnished the image of the Saudi crown prince. Particularly damaging was the conclusion by the CIA that Khashoggi's assassination was conducted at the behest of Mohammed bin Salman. ${ }^{16}$ Ending the 
tion seeking at least $\$ 5$ billion in compensation from the UAE, Saudi Arabia, Bahrain, and Egypt for stopping Qatar from using their airspace. An end to the media war was also agreed upon. Yet, the more fundamental issues have not been addressed. In fact, the Gulf crisis has ended as a result of contingent factors rather than through addressing and solving the issues which have caused it in the first place. The defeat of President Trump in the November 2020 elections and the coming of a less sympathetic and less transactional administration was instrumental in forcing Saudi Arabia, in particular, to end the standoff with Qatar. Riyadh was anticipating troubles with the Biden Administration and it, therefore, sought to sort out some of its regional problems so that it would be better equipped to face pressure from Washington D.C. The economic crisis resulting from the double shock of the collapsing oil prices and COVID-19 has also forced both Saudi Arabia and the UAE to take a less aggressive foreign policy attitude, including toward Qatar. The desire by Saudi Crown Prince Mohammed bin Salman to salvage his international image after the Khashoggi murder and the humanitarian crisis in Yemen have also facilitated the end of the Qatar crisis. Bin Salman must have also sought to show his leadership within the GCC. Although Crown Prince of Abu Dhabi, Mohammed bin Zaid, had played a vital role in garnering support for bin Salman in Washington D.C. during his power struggle with his cousin, Mohammed bin Nayef, bin Salman won't be happy with reports portraying him as if he is led by his junior neighbor in $\mathrm{Abu}$ Dhabi.

Clearly, all these factors, no matter how important they might look, have nothing to do with the root causes of the crisis. This brings to the fore the question of whether the Gulf rivalry has truly been ended or that this was just another respite before animosities resume. Before we see effective mechanisms to resolve intra-Gulf disputes, and a charter that prohibits the use of force, boycott, or blockade in dealing with them is agreed upon, one cannot be sure that the page of the 2017 crisis has been turned over indefinitely.

\section{Endnotes}

1. "The Final Communique of the $41^{\text {st }}$ GCC Supreme Council," The New Arab, (January 5, 2021), retrieved from https://bit.ly/3rVMbEZ.

2. "The Final Communique of the $41^{\text {st }}$ GCC Supreme Council."

3. Jonathan Weisman and Julie Hirschfeld Davis, "Republican Lawmakers Vow Fight to Derail Nuclear Deal," The New York Times, (July 14, 2015), retrieved from https://nyti.ms/2KF9saU.

4. "Trump Takes Credit for Saudi Move against Qatar, a U.S. Military Partner" The New York Times, (June 6, 2017), retrieved from https://www. nytimes.com/2017/06/06/world/middleeast/ trump-qatar-saudi-arabia.html?_r=0.

5. "President Trump's Speech to the Arab Islamic American Summit," The White House, (May 21, 2017), retrieved from https://www.whitehouse. gov/briefings-statements/president-trumpsspeech-arab-islamic-american-summit/.

6. Donald Trump, Twitter, (June 6, 2017), retrieved February 21, 2021, from https://cutt.ly/plsg0Gh.

7. Donald Trump, Twitter, (June 6, 2017), retrieved February 21, 2021, from https://cutt.ly/SIshpn2.

8. "Emir of Qatar and Trump Affirm Strengthening Their Countries' Strategic and Defense Relations," Al Jazeera, (July 9, 2019), retrieved from https://bit.ly/2XqHPsm. 
9. "Qataris, Saudis Make New Bid to Mend a Long-Festering Feud," The Wall Street Journal, (November 28, 2019), retrieved from https://on.wsj. com/2Xgj7tB.

10. "Remarks by President Trump and Emir Sabah al-Ahmed al-Jaber al-Sabah of Kuwait in Joint Press Conference," The White House, (September 7, 2017), retrieved from https://goo.gl/mJn6i6.

11. Marwa Rashad, Ghaida Ghantous, and Jonathan Landay, "Honeymoon Over? Saudi Arabia-U.S. Ties Face Reset with Biden Win," Reuters, (October 22, 2020), retrieved from https://reut. rs/3uiWjZC.

12. Nahal Toosi, "Democrats Want to Rejoin the Iran Nuclear Deal: It's Not That Simple," Politico, (July 20, 2019), retrieved from https://politi. $\mathrm{co} / 3 \mathrm{qTGiHH}$.

13. "UAE Requests Postponement of Expo 2020 Dubai," Middle East Monitor, (April 6, 2020), re- trieved from https://www.middleeastmonitor. com/20200406-uae-requests-postponement-ofexpo-2020-dubai/.

14. Jonathan Gorvett, "How Prepared Is the Gulf for COVID-19?" Castlereagh, (March 6, 2020), retrieved from https://castlereagh.net/how-prepared-is-the-gulf-for-covid-19/.

15. "Gulf Countries to Experience Worst Economic Crisis in History: IIF," The Economic Times, (June 2, 2020), retrieved from https://bit.ly/3pEY67T.

16. Shane Harris, Greg Miller, and Josh Dawsey, "CIA Concludes Saudi Crown Prince Ordered Jamal Khashoggi's Assassination," The Washington Post, (November 17, 2018), retrieved from https:// wapo.st/3pHJggG.

17. Dion Nissenbaum and Stephen Kalin, "Trump Makes Fresh Attempt to Resolve Saudi, Qatar Feud," The Wall Street Journal, (June 3, 2020), retrieved from https://on.wsj.com/2L34WG6. 